\title{
Impacts associated with the recent range shift of the aeolid nudibranch Phidiana hiltoni (Mollusca, Opisthobranchia) in California
}

\author{
Jeffrey H. R. Goddard • Terrence M. Gosliner • \\ John S. Pearse
}

Received: 15 September 2010/ Accepted: 21 January 2011/Published online: 8 February 2011

(C) The Author(s) 2011. This article is published with open access at Springerlink.com

\begin{abstract}
In 1977, Phidiana hiltoni (O'Donoghue in J. Entomol Zool (Pomona College, Claremont, California) 19:77-119, 1927) began spreading northward from Monterey, California. By 1992, it had reached Duxbury Reef $\left(37^{\circ} 53^{\prime} 23^{\prime \prime} \mathrm{N}, 122^{\circ} 41^{\prime} 59^{\prime \prime} \mathrm{W}\right), 100 \mathrm{~km}$ to the north, where other nudibranchs subsequently appeared to decline. The role of $P$. hiltoni in this decline was investigated through diet analysis, feeding trials, and comparison of historical and recent abundance data. In the wild, $P$. hiltoni preyed largely on hydroids, but also showed evidence of predation on nudibranchs. In the laboratory, $P$. hiltoni attacked most of the dendronotid and aeolid nudibranchs presented to it, ingesting small individuals whole. The pooled abundance of nudibranchs vulnerable to attack by $P$. hiltoni declined an average of two-thirds at Duxbury Reef since its arrival, compared to (1) no change in the non-vulnerable species and (2) no change in either group at two other sites where $P$. hiltoni was one to two orders of magnitude less abundant. Phidiana hiltoni therefore
\end{abstract}

Communicated by J. P. Grassle.

Electronic supplementary material The online version of this article (doi:10.1007/s00227-011-1633-7) contains supplementary material, which is available to authorized users.

J. H. R. Goddard ( $\square)$

Marine Science Institute, University of California,

Santa Barbara, CA 93106-6150, USA

e-mail: goddard@lifesci.ucsb.edu

T. M. Gosliner · J. S. Pearse

Department of Invertebrate Zoology and Geology, California

Academy of Sciences, San Francisco, CA 94103, USA

J. S. Pearse

Long Marine Laboratory, University of California,

Santa Cruz, CA 95060, USA appears to have caused this decline, likely through a combination of direct predation and competition for prey. A brief larval period, combined with cyclonic re-circulation in the lee of Point Reyes, may be driving self-recruitment of $P$. hiltoni at Duxbury Reef, as well as hindering further northward spread.

\section{Introduction}

Poleward range shifts driven by global climate change have now been observed in many marine species (Parmesan and Yohe 2003; Perry et al. 2005; Sorte et al. 2010). However, ecological impacts have been documented for only a few of these shifts, especially when compared to analogous cases involving introduced species in their new ranges (Sorte et al. 2010). While invasive species typically spread faster than range-shifting species, the ecological impacts and potential for ecosystem disruption of the two are similar, and the effects of the latter therefore need more attention if we are to fully understand the effects of climate change on biotic interactions and ecosystems (Kintisch 2008; Montoya and Raffaelli 2010; Sorte et al. 2010; Van der Putten et al. 2010; Walther 2010). Here, we document the climaterelated, range expansion of a large aeolid nudibranch in the northeast Pacific Ocean and using dietary analysis, laboratory feeding trials, and comparison of historical and recent abundance data, examine its potential role in the decline of nudibranchs observed at the northern edge of its new range.

The shift from relatively cool to warm coastal ocean temperatures in the NE Pacific Ocean in 1976-1977 triggered numerous biotic responses in the California Current ecosystem (reviewed by McGowan et al. 2003), including northward range expansions of southerly species. This 
climate shift marked the beginning of a warm phase of the Pacific Decadal Oscillation (PDO) (Mantua and Hare 2002), which appears to have persisted until mid-2007 (Mantua 2010). Near the end of a three-year, monthly study of intertidal nudibranchs conducted by JG on the northern end of Monterey Bay (described in Schultz et al. 2011), Phidiana hiltoni, a large and conspicuous aeolid in the family Facelinidae (Fig. 1a), was observed in November 1977 for the first time north of the Monterey Peninsula. By 1992, this species, which grows to $70 \mathrm{~mm}$ in length, had spread $100 \mathrm{~km}$ north to Duxbury Reef, a large shale reef $12 \mathrm{~km}$ northwest of the entrance to San Francisco Bay (Figs. 1b, 3) (Behrens 2004). Since then, P. hiltoni has persisted at Duxbury Reef, where it has often been the most abundant nudibranch present (pers obs).

With its large area, rich intertidal biota, and proximity to the San Francisco Bay Area, Duxbury Reef has been a marine-protected area since 1971 (California Department of Fish and Game 2007). Historically, 45 species of nudibranchs have been recorded from this site, many in abundance (Gosliner and Williams 1970, 1973). However, since

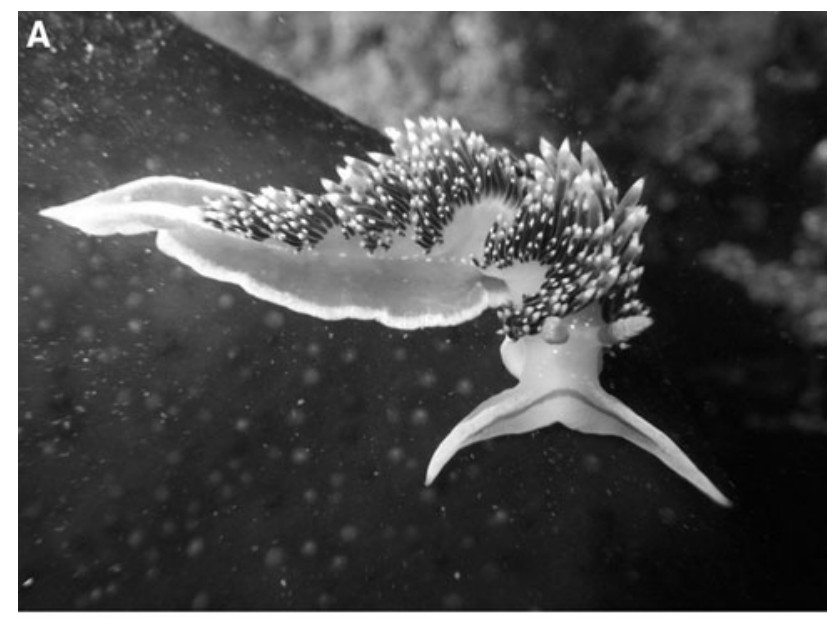

B

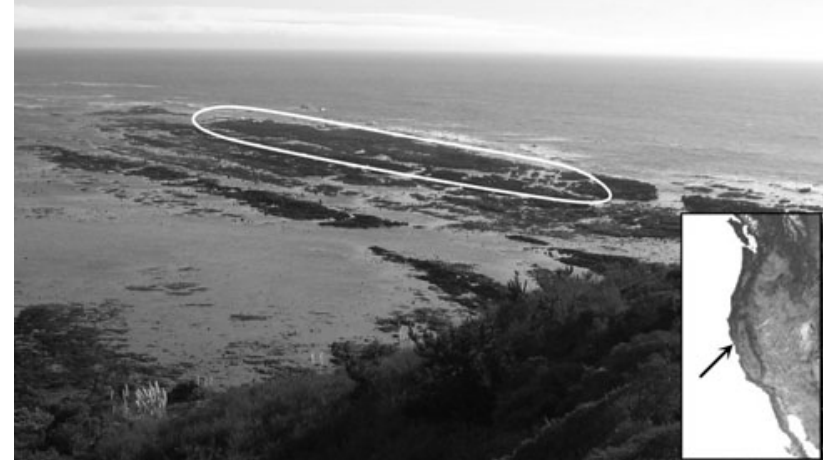

Fig. 1 a Phidiana hiltoni from Pillar Point, California. Image by Douglas Mason. b Outline of study area at Duxbury Reef, Marin County, California, and location of Duxbury Reef on west coast of North America (inset) the arrival of $P$. hiltoni, many nudibranchs at Duxbury Reef appear to have declined in abundance (pers obs).

Although facelinid nudibranchs are known to prey on hydroids and other nudibranchs, particularly aeolids (records summarized by Thompson 1964; Thompson and Brown 1984; McDonald and Nybakken 1997), no one has systematically investigated their feeding on these species, and little has been published on the diet or feeding behavior of $P$. hiltoni. Lance (1962) described P. hiltoni (as $P$. pugnax ${ }^{1}$ ) from southern California as "attacking and dismembering other aeolids upon accidental contact," but presented no details, and this behavior has not been investigated further. MacFarland (1966) described P. hiltoni from Monterey (as P. nigra ${ }^{2}$ ) as "living often on hydroids... occasionally upon kelp." McDonald and Nybakken (1978) reported P. hiltoni feeding on the matforming, colonial hydroid Hydractinia sp. It has also been observed feeding on the thecate hydroid Plumularia sp. (Wight 2000; Green 2009), and subtidal observations indicate that $P$. hiltoni also attacks the solitary corals Balanophyllia elegans and Astrangia lajollensis (Clark 2007; H. Bertsch, pers comm). Both genera of hydroids listed above are known prey of aeolid and dendronotacean species of nudibranchs in the northeast Pacific Ocean (McDonald and Nybakken 1978, 1997; Goddard 1998). Therefore, $P$. hiltoni might exert negative effects on other species of nudibranchs through competition for prey or direct predation and may have affected their abundance at Duxbury Reef.

Here, we document more fully the range expansion of $P$. hiltoni north of Monterey Bay and investigate its diet in the wild and propensity to attack other nudibranchs. Based on the results of the diet studies, behavioral trials, and taxonomic affinity, we group nudibranchs from Duxbury Reef according to their demonstrated or inferred vulnerability to predation by $P$. hiltoni. We then utilize historical abundance data from Duxbury Reef and two other sites, combined with recently obtained survey data from all three sites, to compare the abundance of these groups at each site before and after the arrival of $P$. hiltoni. We reasoned that if $P$. hiltoni negatively affects other species of nudibranchs, then those impacts should be greatest where it has become most abundant in its new range.

\footnotetext{
${ }^{1}$ McDonald (1983) synonymized Phidiana pugnax with P. hiltoni, and no evidence exists that Lance (1962) was aware of O'Donoghue's (1927) description of Facelina hiltoni.

2 MacFarland's posthumous, 1966 description of $P$. nigra from the Monterey Peninsula was synonymized with $P$. pugnax by Roller (1970). No evidence exists that either P. nigra or P. pugnax were recorded from north of Monterey, California.
} 


\section{Materials and methods}

Study site and sampling methods

Duxbury Reef (Figs. 1b, 3) extends $0.75 \mathrm{~km}$ SSE from Duxbury Point, Bolinas, and is the largest shale reef on the Pacific coast of North America. The point and reef form the western end of Bolinas Bay, a small, south-facing embayment $6.5 \mathrm{~km}$ wide at its mouth. The study area consisted of channels, pools, and overhanging ledges in an area on the outer half of the reef and extending back approximately $20 \mathrm{~m}$ from its southwestern edge (Fig. 1b). Composed of easily fractured and eroded mudstone, many of the pools and channels are lined with cobble. Loose material is constantly sloughing off nearby cliffs, and during periods of high wave action and runoff, local waters are turbid with suspended sediments. Circulation in Bolinas Bay is primarily cyclonic (Wilde et al. 1969).

To estimate nudibranch population abundance prior to the arrival of Phidiana hiltoni, we used timed counts $(n=5)$ of nudibranchs conducted by TG in June and July 1969, January and June 1970, and June 1972, and three by JG in December 1974 and May and December 1975. Since December 2007 we have conducted, roughly quarterly, an additional 11 timed counts of nudibranchs in the same area as the original counts. We avoided sampling during conditions that could impede the counts, particularly high wave surge and rainfall. For all analyses, we standardized nudibranch counts to number of individuals $\mathrm{h}^{-1}$ observer $^{-1}$ or number of species $\mathrm{h}^{-1}$ observer $^{-1}$. TG and (or) JG conducted all counts during both time periods, assisted at times by experienced observers familiar with intertidal nudibranchs from California. Therefore, we consider minimal any effect of observer on the counts.

\section{Diet analysis}

To characterize the diet of $P$. hiltoni on rocky shores in central California, we examined the fecal material of a total of 62 specimens collected from four localities: Duxbury Reef; Hazard Canyon, Montana de Oro State Park (35 $17^{\prime}$ $23^{\prime \prime} \mathrm{N} 120^{\circ} 53^{\prime} 02^{\prime \prime} \mathrm{W}$ ); Tarantula Reef, Jalama Beach (34 $29^{\prime} 43^{\prime \prime} \mathrm{N} 120^{\circ} 29^{\prime} 50^{\prime \prime} \mathrm{W}$ ); and the Ellwood boulder field on the Gaviota coast of Santa Barbara County ( $34^{\circ} 26^{\prime} 02^{\prime \prime}$ $\left.\mathrm{N} 119^{\circ} 57^{\prime} 02^{\prime \prime} \mathrm{W}\right)$. Upon collection, each individual was isolated in a $250-\mathrm{ml}$ plastic container of clean seawater and held for 1-2 days. Fecal material from each individual was then collected and examined with dissecting and compound microscopes, and all presumed prey items identified to the lowest taxonomic level practical using the keys in Carlton (2007), especially that for hydrozoan polypoid stages by Marques et al. (2007). Although the chitinous exoskeleton, or perisarc, of the hydroids passed unchanged through the guts of the P. hiltoni, the opercular valves at the aperture of the hydrothecae of some thecate species were typically missing, precluding their identification lower than the family level. Individual taxa were counted if rare, or noted as frequent or abundant in each sample, and diet for all individuals was summarized based on the presence or absence of individual prey items.

To confirm the previous observations of $P$. hiltoni feeding on hydroids summarized earlier, in the laboratory we presented $P$. hiltoni separately (1) hydrocauli of Plumularia laginifera collected from Coleman Beach and the Ellwood boulder field and (2) pieces of colonies of Hydractinia sp. collected from Hazard Canyon and Duxbury Reef, respectively.

Feeding trials using other nudibranchs

To test the propensity of $P$. hiltoni to attack and consume other nudibranchs, we held adult $P$. hiltoni in isolation in 250-ml containers for one to two days following collection. Each trial consisted of placing one $P$. hiltoni in about $300 \mathrm{ml}$ of fresh seawater in a bowl (18.5-cm top diameter and $7-\mathrm{cm}$ flat bottom diameter) and letting it begin crawling on the bottom of the bowl. We then added an individual of one of the test species near the anterior of the $P$. hiltoni and using blunt forceps, gently prodded it into crawling directly toward the head of $P$. hiltoni. Following its contact with the test individual, we categorized the behavior of the $P$. hiltoni as follows: (1) rapid withdrawal of head, immediately followed by a change of direction of crawling, (2) withdrawal of head, but no significant change of direction (3) neutral, or no apparent response, (4) repeated contact with the test individual, but no attempt to consume it, and (5) attack and attempt to consume the test individual. We also recorded the behavior of the test individual, noting especially any escape behavior (swimming or rapid change of direction of crawling) following contact with $P$. hiltoni. We did not time the behavioral interactions. However, the outcome of each trial was generally apparent immediately following contact for adverse reactions by $P$. hiltoni and took up to a few minutes in trials in which $P$. hiltoni investigated or attacked the test species.

We used a total of $48 P$. hiltoni, 30-54 mm long, in 154 trials, and 21 species of test nudibranchs. For test species, we focused on small $(<15 \mathrm{~mm})$ individuals whose diets are known or suspected (based on records in McDonald and Nybakken 1978, 1997; Goddard 1984, 1998, pers obs) to overlap with that of $P$. hiltoni as determined in this study. As outliers (see next section), we also used two soft-bodied dorid nudibranchs (Triopha maculata and Ancula gibbosa) known to consume different prey (in this case, bryozoans and kamptozoans, respectively). Individuals of the test species were 3-14 $\mathrm{mm}$ long, except for Hermissenda 
crassicornis, which were 6-40 mm long. Most of the $P$. hiltoni used in these trials were a subset of the same individuals first used in the diet analysis; all were collected from the same four localities listed earlier, with the majority, for logistical reasons, coming from the three more southerly sites.

Initially, we switched individuals of $P$. hiltoni between trials. However, after observing some adverse reactions by $P$. hiltoni to small aeolids, especially Cuthona lagunae, we decided to check the behavior of $P$. hiltoni by running sets of consecutive trials using one $P$. hiltoni and a test species previously found to elicit an adverse reaction by $P$. hiltoni, followed by one we had observed to be ingested, and vice versa. In virtually all cases, the order of these trials had no effect on the species-specific outcome we had observed previously, so we considered these trials effectively independent and thereafter ran sets of two to four consecutive trials before switching individuals of $P$. hiltoni. We also switched individuals when they had consumed two test slugs in any set of consecutive trials. Forceps were rinsed in fresh water following each trial, and the bowl rinsed and seawater changed each time a new $P$. hiltoni individual was used.

We conducted another set of trials to investigate potential effects of food deprivation on the behavioral responses of $P$. hiltoni to Hermissenda crassicornis, an aeolid nudibranch common in California. We collected eight $P$. hiltoni, $25-44 \mathrm{~mm}$ long and a single $H$. crassicornis, $6 \mathrm{~mm}$ long, from Tarantula Reef, Jalama Beach on 15 Dec 2009. The following day, we conducted behavioral trials similar to above, except that we conducted these in the individual holding containers of the $P$. hiltoni and therefore only moved the $H$. crassicornis between trials. We exposed, in turn, each of the $P$. hiltoni to the single H. crassicornis. We then repeated these trials on Dec 17, 22, and 23. Neither the P. hiltoni nor the H. crassicornis received any food after collection on 15 Dec. Only the initial set of eight trials conducted on 16 Dec was included in the overall compilation of behavioral trials using these two species (see Table 2).

\section{Comparison of nudibranch abundance \\ before and after the arrival of Phidiana hiltoni}

To compare the abundance of nudibranchs at Duxbury Reef before and after the arrival of $P$. hiltoni, we first assigned nudibranch species known from this site as vulnerable or not to predation by $P$. hiltoni based on the following criteria: (1) whether or not they were consumed by $P$. hiltoni in the laboratory feeding trials and (2) whether their known diets overlapped with the diet of $P$. hiltoni as determined in this study. Small aeolids specializing on hydroids also consumed by $P$. hiltoni might be consumed incidentally by the latter as it ingests whole branches or colonies. In addition, we considered taxonomic affinity. Some facelinids are known to prey on dendronotid and aeolid nudibranchs, but none have been reported to attack dorid nudibranchs (Alder and Hancock 1846; and see records summarized by McDonald and Nybakken 1997). For example, Garcia and Garcia (1984) reported that the facelinid Dondice banyulensis consumed three species of aeolids, but did not attack dorids from three different families presented to it. Aside from diverse chemical defenses against predators, many dorids have highly spiculate mantle tissues (Thompson 1976; Penney 2006). These impart rigidity to the body and may hinder ingestion by some predators specializing on opisthobranchs (e.g., Paine 1963). Moreover, P. hiltoni cannot open its mouth very wide (pers obs) and would be able to physically ingest only juveniles of spiculate dorids, most of which grow to sizes much larger than the width of the head of $P$. hiltoni. If the two relatively small, soft-bodied dorids we tested were not attacked or ingested by $P$. hiltoni, then we assumed all of the dorid nudibranchs known from Duxbury Reef and the region were not vulnerable to attack by $P$. hiltoni.

We used JMP 8.0 (SAS Institute, Inc.) to compare the mean pooled abundance of each of the above two groups of nudibranchs for the two time periods by using $t$-tests assuming unequal variances. We used a one-tailed test for the vulnerable group, based on the expectation that their abundance would decline following the arrival of $P$. hiltoni, and a two-tailed test for the group of species not vulnerable to $P$. hiltoni.

For the above analysis, we averaged counts made within 2 months of each other (June and July 1969, April and June 2008, and October and December 2009) and then excluded sample dates (April 2009 only) separated by less than 4 months in order to minimize potential autocorrelation between counts. In this analysis, we also excluded one anomalously low sample (October 2008), in which three observers searching for $1 \mathrm{~h}$ found only a single nudibranch. Schultz et al. (2011) found a positive correlation between the multivariate El Niño-Southern Oscillation (ENSO) index (MEI, Wolter and Timlin 1993) and total abundance of nudibranchs intertidally at three sites in central California, and our data from Duxbury Reef are consistent with this finding (Fig. 2). Owing to the potentially large influence of this factor on our abundance comparison, we controlled for it by using approximately the same number of sample dates falling under La Niña, El Niño, and ENSOneutral conditions, before and after the arrival of $P$. hiltoni. Following Schultz et al. (2011), we defined La Niña as mean MEI for the 6 months preceding the sample date $\leq-0.5$, El Niño as the mean $\geq 0.5$, and ENSO neutral as between these values. By this definition, we had only one data point (mean of June and July 1969) from the early 


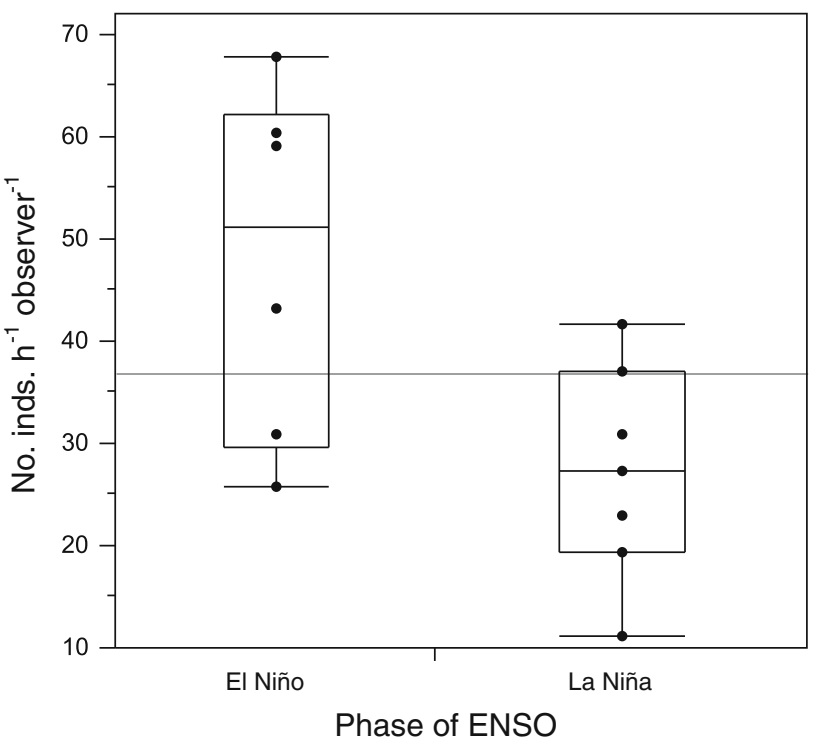

Fig. 2 Box plots of abundance of all nudibranchs pooled at Duxbury Reef by phase of ENSO as measured by the mean Multivariate ENSO Index (MEI, Wolter and Timlin 1993) over the 6 months prior to each sample date, 1969-1975, 2007-2010. Here, we defined La Niña as mean MEI $\leq-0.5$ and El Niño as mean MEI $\geq 0.5$. Plots depict, for each group of data points, the median, upper and lower quartiles, minimum and maximum

time period falling under El Niño conditions (6 mo. Mean MEI = 0.621). With three data points from the stronger 2009-2010 El Niño, we therefore used one (mean of October and December 2009, with mean MEI $=0.763$ ) and omitted two (Jan 2010 and May 2010, with mean MEIs > 1). Five of the other points were ENSO neutral (three from 1969-1975 and two from 2007-1909) and five were from La Niñas (three and two, respectively). Samples dates used in these analyses are shown in Fig. 4.

We conducted similar analyses, controlling as above for phase of ENSO, using timed counts of nudibranchs made at two other rocky intertidal sites within the new (post-1977) range of P. hiltoni: Scott Creek and Pillar Point (Fig. 3). A fixed area at Scott Creek was sampled monthly (by JG) from June 1975 to June 1978, intermittently from October 1978 to June 2006, and then quarterly from December 2007 to July 2010. Douglas Mason and William Pence sampled a fixed area at Pillar Point largely monthly from September 1988 to February 1995 and quarterly from January 2008 to June 2010. These two study areas are described more fully by Schultz et al. (2011), with links to the complete abundance data.

To evaluate the alternative hypothesis that abundance changes at Duxbury Reef were influenced more by species' geographic range than their vulnerability to $P$. hiltoni (e.g., like $P$. hiltoni, other southern species might have increased between the two time periods, compared to northern species), we assigned nudibranch species to geographic range groups following Schultz et al. (2011), who defined (1) southern species as those with northern range limits typically in northern California or southern Oregon, (2) northern species as those with southern limits in southern California or northern Baja California, and (3) widespread species as those extending both north of the southern species and south of the northern species. We then compared the number of species that tended to increase or decrease in abundance, grouped by geographic range and vulnerability to $P$. hiltoni.

\section{Results}

Range expansion of Phidiana hiltoni

Phidiana hiltoni was originally described by O'Donoghue (1927) based on specimens from Laguna Beach, in southern California. Its northern geographic range limit was the Monterey Peninsula until the 1970s (Fig. 3) (Costello 1938, Table 1 [as "Aeolid (maroon-black cerata)"]; MacFarland 1966 [as P. nigra]; Nybakken 1978 [as P. nigra]). It was not recorded in surveys of nudibranchs conducted north of Monterey between the late 1940s and early 1970s (Fig. 3; Appendix in ESM; Steinberg 1963; Gosliner and Williams 1970, 1973; Bertsch et al. 1972). Following the observation of the first specimen at Scott Creek in November 1977 (see "Introduction"), JG found three more specimens at the same site in monthly surveys conducted from Dec 1977 to June 1978, a total of 15 more specimens in five of seven surveys of the same site conducted between July 1984 and September 1993, and 22 specimens in 11 of 15 surveys from Dec 2007 to July 2010 (Schultz et al. 2011; JG unpub data). In 1996 and 1997, JSP and UCSC biology classes resurveyed over four academic quarters the same 10 sites originally examined in 1971-1973, this time finding P. hiltoni at four sites (Appendix; Zabin et al. in prep.). At two of these sites (Santa Cruz and Soquel Points; see Fig. 3), $P$. hiltoni was observed in three of the four quarters of the 1996-1997 surveys. On 2 Dec 2009, 67 specimens of $P$. hiltoni were found in the low intertidal at Soquel Point, compared to a total of 18 specimens of three other species (B. Green, pers comm).

On the San Mateo County coastline, P. hiltoni was first recorded from Pillar Point in January 1991 (Schultz et al. 2011). It has since been found in the adjacent Fitzgerald Marine Reserve (S. Lenz, pers comm) and at Bean Hollow State Beach (Albers-Mead 2006).

By December 1992, P. hiltoni was already abundant at Duxbury Reef (pers obs). Since 2007, we have observed up to six individuals $\mathrm{m}^{-2}$ in the tidepools at Duxbury Reef, and it has consistently been one of the most abundant 


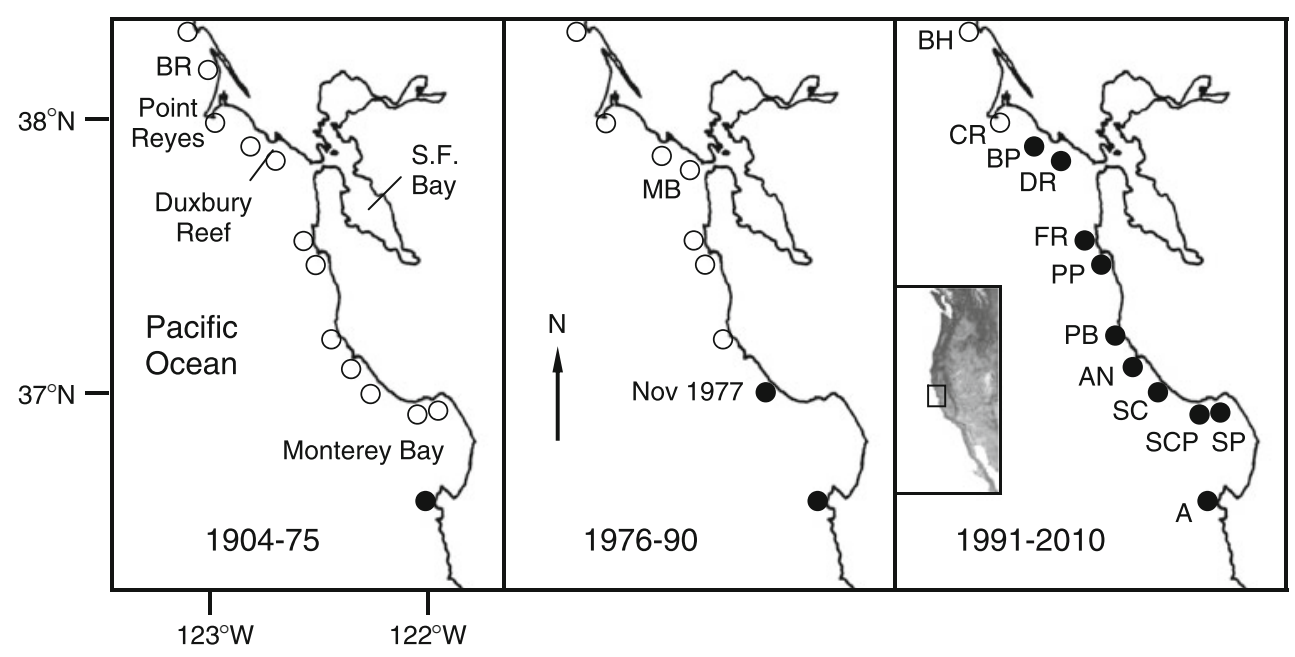

Fig. 3 Northern range shift of $P$. hiltoni on west coast of North America (inset). Open circles represent negative records; filled circles, positive records (based on records and references in Appendix). Not shown are negative records, obtained since 1992, from north of Bodega Head, or negative records from Drake's Estero, near Point Reyes (see Appendix). Site codes: A Asilomar, AN Año

nudibranchs present, averaging over 10 individuals $\mathrm{h}^{-1}$ observer $^{-1}$ (see Table 3 below).

Diet of Phidiana hiltoni in the wild

A total of 20 taxa were found in the fecal material of $P$. hiltoni (Table 1). Eight taxa were hydroids, comprising $82 \%$ of the prey records, with Plumularia spp. the most frequent. Nudibranch cerata were observed in the feces of three individuals. Two cerata were from $P$. hiltoni, as indicated by the distinctive color of the digestive diverticulum, and the ceras in the feces of a $P$. hiltoni collected from Duxbury Reef was from a different aeolid nudibranch, likely either Cuthona fulgens or Hermissenda crassicornis, based on its orange and white color. One individual from Duxbury had ingested an egg mass of $P$. hiltoni, as evidenced by the length of the egg mass covering and the late-stage embryos with eyespots and propodium. Many of the embryos were viable and had hatched from their egg capsules, presumably after being expelled in the feces of the adult $P$. hiltoni, but others had been digested and consisted of empty shells. Another individual from Duxbury Reef had significant amounts of amorphous soft tissue in the feces, possibly the remains of a nudibranch.

In the laboratory, $P$. hiltoni readily consumed hydrocauli of Plumularia laginifera, including colonies from Coleman Beach, $60 \mathrm{~km}$ north of the current geographic range of $P$. hiltoni. The slugs bit off whole sections of hydrocauli, leaving only a stump after a few bites. One P. hiltoni, $36 \mathrm{~mm}$ long and collected from the Ellwood boulder field,
Nuevo Cove, $B H$ Bodega Head, $B P$ Bolinas Point, $B R$ Bird Rock, $C R$ Chimney Rock, $D R$ Duxbury Reef, $F R$ Fitzgerald Marine Reserve, $M B$ Muir Beach, $P B$ Pescadero State Beach and Bean Hollow State Beach, PP Pillar Point, SC Scott Creek, SCP Santa Cruz Point East, $S P$ Soquel Point

also consumed Hydractinia sp. from Hazard Canyon, consuming $8 \mathrm{~mm}^{2}$ of a colony fragment in $5 \mathrm{~min}$ and the remaining $19 \mathrm{~mm}^{2}$ of that fragment within $3 \mathrm{~h}$. Four $P$. hiltoni collected from Duxbury Reef and held without food for 2 days immediately started feeding on a colony (approximately $600 \mathrm{~mm}^{2}$ ) of Hydractinia sp., also collected from Duxbury Reef.

Feeding trials using other nudibranchs

Phidiana hiltoni attacked 15 of the 21 species of nudibranchs presented to it, ingesting individuals of all 15 , whole or in part (Table 2). Doto columbiana, Doto form A of Goddard (1996), Cuthona divae, Cuthona albocrusta, and Aeolidia papillosa were especially vulnerable to attack and were not observed to repel P. hiltoni. In contrast, Cuthona lagunae, one Eubranchus rupium, and one 9-mmlong Dirona picta always repelled P. hiltoni, or at most caused no visible reaction. The two dorids tested, Triopha maculata and Ancula gibbosa, tended to elicit neutral responses, and the remaining species elicited variable responses by $P$. hiltoni, ranging from aversion to attack and ingestion (Table 2).

Flabellina trilineata, Flabellina cf. trilineata, and Hermissenda crassicornis usually caused $P$. hiltoni to withdraw and change direction on contact. However, in a few instances, $P$. hiltoni would pursue, repeatedly contact, and finally ingest whole or part of individuals of these species. In the case of $H$. crassicornis, three of the four attacks recorded were made by $P$. hiltoni collected from Duxbury Reef, representing three of the five trials conducted using 
Table 1 Taxa consumed by Phidiana hiltoni and identified from their fecal matter
Values are number of $P$. hiltoni from each site that had consumed each taxon, and total number $(N)$ of slugs across all sites that had consumed each prey item. Site codes: Ell Ellwood, Jal Jalama, Haz Hazard Canyon, Dux Duxbury Reef. Nomenclature follows Carlton (2007)

a Samples of Plumularia sp. defecated by individuals from Jalama keyed to P. laginifera, and although this species appeared to predominate in fecal samples from all sites, we did not attempt to identify all fragments of Plumularia spp. to species

\begin{tabular}{|c|c|c|c|c|c|}
\hline \multirow[t]{2}{*}{ Prey item } & \multicolumn{4}{|c|}{ Site } & \multirow{2}{*}{$\begin{array}{l}\text { Tota } \\
N\end{array}$} \\
\hline & Ell & Jal & $\mathrm{Haz}$ & Dux & \\
\hline \multicolumn{6}{|l|}{ Cnidaria: Hydrozoa } \\
\hline Plumularia spp. $^{\mathrm{a}}$ & 10 & 10 & & 8 & 28 \\
\hline Campanulariidae (stolonal, unbranched) & 2 & 15 & 1 & 6 & 24 \\
\hline Unident. A (Anthoathecata with annulate perisarc) & & 14 & & 4 & 18 \\
\hline Unident. B (with frosted-looking perisarc) & 1 & 12 & & & 13 \\
\hline Sertulariidae (with opposite to subalternate hydrothecae) & & & & 6 & 6 \\
\hline Campanulariidae (erect, branched) & & 3 & & & 3 \\
\hline Unident. C (smooth perisarc) & 1 & 1 & & & 2 \\
\hline Unident. D (Anthoathecata with filiform tentacles) & & 1 & & & 1 \\
\hline \multicolumn{6}{|l|}{ Other taxa } \\
\hline Arachnida: Acari (mites) & & & & 4 & 4 \\
\hline Foraminifera, diatoms, filamentous algae & & 2 & & 1 & 3 \\
\hline Nudibranchia (ceras from $P$. hiltoni) & & 2 & & & 2 \\
\hline Bryozoa: Cyclostomatida (erect, branched) & & 1 & & 1 & 2 \\
\hline Cnidaria: Anthozoa (tentacle only) & & & 1 & & 1 \\
\hline Bryozoa: Cheilostomatida: Anascina (erect, branched) & & 1 & & & 1 \\
\hline Nudibranchia (egg mass and embryos of $P$. hiltoni) & & & & 1 & 1 \\
\hline Nudibranchia (tip of ceras from unident. aeolid) & & & & 1 & 1 \\
\hline Crustacea: Ostracoda & & 1 & & & 1 \\
\hline Crustacea: Amphipoda & & & 1 & & 1 \\
\hline Unident. crustacean & & & & 1 & 1 \\
\hline Unident. soft tissue & & & & 1 & 1 \\
\hline None & & 1 & 1 & & 2 \\
\hline & & & & & \\
\hline \# Phidiana hiltoni examined & 10 & 33 & 4 & 15 & \\
\hline
\end{tabular}

$P$. hiltoni from Duxbury Reef and $H$. crassicornis $<15 \mathrm{~mm}$ long (data not shown).

Despite attacks by $P$. hiltoni, one individual each of Aeolidia papillosa, Cuthona flavovulta, and Hermissenda crassicornis escaped unharmed (Table 2). These individuals were 14,6 , and $14 \mathrm{~mm}$ long, respectively, and had been attacked by $P$. hiltoni 37,46 , and $35 \mathrm{~mm}$ long, respectively.

In the group of trials using eight $P$. hiltoni and a single 6-mm-long Hermissenda crassicornis collected from Jalama Beach, there was virtually no difference in the behavioral reactions of $P$. hiltoni between the initial set of trials and those conducted one, six, and seven days later. In 29/32 total trials, $P$. hiltoni rapidly withdrew its head and changed direction of crawling following contact with $H$. crassicornis. The response in one trial was neutral, and in two trials, $P$. hiltoni made repeated contact with $H$. crassicornis before finally turning away.

Some individuals of Dendronotus venustus and Hermissenda crassicornis showed distinct escape behaviors in response to contact by $P$. hiltoni. Hermissenda crassicornis raised its cerata, twisted it body violently, and then crawled away rapidly; $P$. hiltoni followed but gave up after a few seconds. Dendronotus venustus lifted off the substratum and swam a short distance from $P$. hiltoni by lateral flexations of its body. Both behaviors were elicited by simple contact with $P$. hiltoni, before it attacked.

Abundance of nudibranchs at Duxbury Reef before and after the arrival of Phidiana hiltoni

In the 15 timed counts used in the comparison of abundance, before and after the arrival of $P$. hiltoni, we recorded 39 species of nudibranchs, plus $P$. hiltoni (Table 3 ). Based on the criteria described earlier, we considered 14 of these vulnerable to predation by $P$. hiltoni and the remaining 25 species not vulnerable. Abundance changes for P. hiltoni and the vulnerable and non-vulnerable species most abundant prior to the arrival of $P$. hiltoni are shown in Fig. 4.

At Duxbury Reef, the pooled abundance of the 14 vulnerable species declined an average of two-thirds following the arrival of $P$. hiltoni, which averaged $10.44 \pm 5.71$ individuals $\mathrm{h}^{-1}$ observer $^{-1} \quad\left(t_{8.7}=-2.55, \quad P=0.02\right)$ (Fig. 5a). There was no significant difference in the pooled 
Table 2 Behavioral reactions of Phidiana hiltoni to test nudibranchs

\begin{tabular}{|c|c|c|c|c|c|c|c|}
\hline \multirow[t]{3}{*}{ Test species } & \multicolumn{7}{|c|}{ Reaction of $P$. hiltoni } \\
\hline & \multirow[t]{2}{*}{ Withdraw, Turn } & \multirow[t]{2}{*}{ Withdraw } & \multirow[t]{2}{*}{ Neutral } & \multirow[t]{2}{*}{ Repeat contact } & \multicolumn{3}{|c|}{ Attack and ingest } \\
\hline & & & & & Whole & Part & Fail \\
\hline \multicolumn{8}{|l|}{ Doridina } \\
\hline Triopha maculata $(4,8)$ & & & 5 & 3 & & & \\
\hline Ancula gibbosa $(4,5)$ & & 1 & 4 & & & & \\
\hline \multicolumn{8}{|l|}{ Dendronotina } \\
\hline Doto columbiana $(7,7)$ & & & & & 6 & 1 & 0 \\
\hline Doto form A $(4,6)$ & & & & & 3 & 3 & 0 \\
\hline Doto amyra $(6,8)$ & & & & 2 & 3 & 3 & 0 \\
\hline Tritonia myrakeenae $(4,9)^{\mathrm{a}}$ & & & 3 & 3 & 2 & 1 & 0 \\
\hline Doto kya $(6,10)$ & & 2 & 1 & 1 & 6 & 0 & 0 \\
\hline Dendronotus venustus $(6,7)$ & 1 & 1 & 1 & & 4 & 0 & 0 \\
\hline Dendronotus subramosus $(1,1)$ & & 1 & & & & & \\
\hline \multicolumn{8}{|l|}{ Arminina } \\
\hline Dirona picta $(1,2)$ & 2 & & & & & & \\
\hline \multicolumn{8}{|l|}{ Aeolidina } \\
\hline Aeolidia papillosa $(3,3)$ & & & & & 2 & 0 & 1 \\
\hline Cuthona divae $(3,3)$ & & & & & 1 & 2 & 0 \\
\hline Cuthona albocrusta $(6,7)$ & & & 1 & & 6 & 0 & 0 \\
\hline Aeolidiella chromosoma $(2,4)^{\mathrm{a}}$ & 1 & & & & 0 & 3 & 0 \\
\hline Cuthona flavovulta $(4,8)$ & 3 & & 1 & 2 & 1 & 0 & 1 \\
\hline Eubranchus rustyus $(3,6)$ & 2 & & 1 & & 1 & 2 & 0 \\
\hline Flabellina trilineata $(3,10)$ & 8 & & & & 2 & 0 & 0 \\
\hline Flabellina cf. trilineata $(3,6)^{\mathrm{b}}$ & 4 & & & 1 & 1 & 0 & 0 \\
\hline Hermissenda crassicornis $(10,31)$ & 23 & & 2 & 2 & 2 & 1 & 1 \\
\hline Cuthona lagunae $(6,11)$ & 9 & 1 & 1 & & & & \\
\hline Eubranchus rupium $(1,2)$ & 2 & & & & & & \\
\hline
\end{tabular}

Shown are number of trials in which $P$. hiltoni reacted according to five categories of behavior, ranging from adversely (left), to attacking (right). If attacked, test slugs were ingested whole or in part, or escaped. Forty-eight $P$. hiltoni were used in 154 total trials. Numbers in parentheses after test species are number of individuals of that species used, and total number of trials conducted using that species

${ }^{a}$ Species does not occur as far north as Duxbury Reef

${ }^{\mathrm{b}}$ Unlike $F$. trilineata, this form has smooth to slightly wrinkled rhinophores, and on the body has three white longitudinal bands of irregular width. It appears to be an undescribed species

abundance of the non-vulnerable species before and after the arrival of $P$. hiltoni (Fig. 5a), nor was there any difference in the number of species in either group of nudibranchs between the two time periods (Fig. 5b).

At both Pillar Point and Scott Creek, where P. hiltoni averaged 1.69 and 0.36 individuals $\mathrm{h}^{-1}$ observer $^{-1}$, respectively, the vulnerable species tended to increase in abundance following the arrival of $P$. hiltoni (Fig. 6). However, these trends were not significant at either Pillar Point $\left(t_{4.5}=1.35, P=0.24\right.$, two-tailed test $)$ or Scott Creek $\left(t_{8.3}=1.59, P=0.15\right.$, two-tailed test), and there was also no significant difference in the before/after change in abundance of the non-vulnerable species.
From 1969-1975 to 2007-2009, similar proportions of species vulnerable or not to $P$. hiltoni tended to increase or decrease in abundance (Tables 3 and 4). However, the vulnerable species initially most abundant tended to decrease, led by a significant decline in Hermissenda crassicornis, while the two most abundant non-vulnerable species (Triopha catalinae and T. maculata) tended to increase (Table 3). Factoring in geographic range (vulnerable species contained fewer southern and widespread species, more of which tended to decrease compared to northern species), vulnerable species appear to have been more likely to decline in abundance (Table 4). 
Table 3 Abundance of nudibranchs recorded in timed counts at Duxbury Reef, before $(n=7)$ and after $(n=5)$ arrival of Phidiana hiltoni

\begin{tabular}{|c|c|c|c|c|c|c|c|}
\hline \multirow[t]{2}{*}{ Species } & \multirow[t]{2}{*}{ Taxon } & \multirow{2}{*}{$\begin{array}{l}\text { Vulnerable to } \\
\text { P. hiltoni }\end{array}$} & \multicolumn{2}{|c|}{ Mean $( \pm \mathrm{SD})$ no. inds. $\mathrm{h}-1$ obs. -1} & \multirow[t]{2}{*}{$\Delta$} & \multirow[t]{2}{*}{$P$} & \multirow{2}{*}{$\begin{array}{l}\text { Geog } \\
\text { range }\end{array}$} \\
\hline & & & $1969-1975$ & $2007-2009$ & & & \\
\hline Triopha catalinae (Cooper, 1863) & Dor & No & $3.59 \pm 2.32$ & $7.98 \pm 12.39$ & + & 0.87 & $\mathrm{~N}$ \\
\hline Triopha maculata MacFarland, 1905 & Dor & No & $2.32 \pm 2.40$ & $2.59 \pm 2.90$ & + & 0.97 & $S$ \\
\hline Rostanga pulchra MacFarland, 1905 & Dor & No & $2.20 \pm 2.94$ & $0.00 \pm 0.00$ & - & 0.02 & $\mathrm{~W}$ \\
\hline Cadlina modesta MacFarland, 1966 & Dor & No & $2.03 \pm 2.66$ & $0.00 \pm 0.00$ & - & 0.02 & $\mathrm{~W}$ \\
\hline Aegires albopunctatus MacFarland, 1905 & Dor & No & $1.58 \pm 3.09$ & $0.25 \pm 0.35$ & - & 0.28 & $\mathrm{~W}$ \\
\hline Diaulula sandiegensis (Cooper, 1863) & Dor & No & $1.55 \pm 1.44$ & $1.07 \pm 1.23$ & - & 0.52 & $\mathrm{~W}$ \\
\hline $\begin{array}{l}\text { Dirona picta MacFarland in Cockerell } \\
\text { and Eliot, } 1905\end{array}$ & Arm & No & $1.24 \pm 2.88$ & $0.00 \pm 0.00$ & - & 0.22 & S \\
\hline Doris montereyensis Cooper, 1863 & Dor & No & $0.73 \pm 1.00$ & $1.16 \pm 1.90$ & + & 0.79 & $\mathrm{~N}$ \\
\hline Diaphorodoris lirulatocauda Millen, 1985 & Dor & No & $0.70 \pm 1.08$ & $1.75 \pm 3.50$ & + & 0.71 & W \\
\hline Cuthona lagunae (O’Donoghue, 1926) & Aeo & No & $0.51 \pm 0.35$ & $0.27 \pm 0.60$ & - & 0.30 & $\mathrm{~S}$ \\
\hline Ancula gibbosa (Risso, 1818) & Dor & No & $0.50 \pm 0.51$ & $0.42 \pm 0.55$ & - & 0.79 & $\mathrm{~N}$ \\
\hline Cadlina luteomarginata MacFarland, 1966 & Dor & No & $0.39 \pm 0.34$ & $0.05 \pm 0.12$ & - & 0.04 & $\mathrm{~N}$ \\
\hline Acanthodoris lutea MacFarland, 1925 & Dor & No & $0.35 \pm 0.29$ & $0.00 \pm 0.00$ & - & 0.02 & $\mathrm{~S}$ \\
\hline Doriopsilla albopunctatus (Cooper, 1863) & Dor & No & $0.33 \pm 0.48$ & $0.00 \pm 0.00$ & - & 0.10 & $\mathrm{~S}$ \\
\hline Acanthodoris nanaimoensis O’Donoghue, 1921 & Dor & No & $0.21 \pm 0.24$ & $0.10 \pm 0.22$ & - & 0.40 & $\mathrm{~N}$ \\
\hline Janolus fuscus O’Donoghue, 1924 & Arm & No & $0.17 \pm 0.25$ & $0.13 \pm 0.30$ & - & 0.78 & $\mathrm{~N}$ \\
\hline Limacia cockerelli (MacFarland, 1905) & Dor & No & $0.14 \pm 0.20$ & $0.00 \pm 0.00$ & - & 0.10 & $\mathrm{~W}$ \\
\hline Peltodoris nobilis (MacFarland, 1905) & Dor & No & $0.12 \pm 0.22$ & $0.35 \pm 0.65$ & + & 0.51 & $\mathrm{~N}$ \\
\hline Geitodoris heathi (MacFarland, 1905) & Dor & No & $0.10 \pm 0.12$ & $0.20 \pm 0.45$ & + & 0.73 & $\mathrm{~N}$ \\
\hline $\begin{array}{l}\text { Acanthodoris rhodoceras Cockerell } \\
\text { and Eliot, } 1905\end{array}$ & Dor & No & $0.08 \pm 0.11$ & $0.00 \pm 0.00$ & - & 0.09 & $\mathrm{~S}$ \\
\hline Hallaxa chani Gosliner and Williams, 1975 & Dor & No & $0.05 \pm 0.10$ & $0.10 \pm 0.22$ & + & 0.73 & $\mathrm{~N}$ \\
\hline Onchidoris muricata (Linnaeus, 1767) & Dor & No & $0.02 \pm 0.06$ & $0.00 \pm 0.00$ & - & 0.36 & $\mathrm{~N}$ \\
\hline Dendronotus albus Robilliard, 1970 & Den & No & $0.01 \pm 0.02$ & $0.00 \pm 0.00$ & - & 0.36 & $\mathrm{~N}$ \\
\hline Dendronotus subramosus MacFarland, 1966 & Den & No & $0.01 \pm 0.02$ & $0.15 \pm 0.34$ & + & 0.41 & $\mathrm{~N}$ \\
\hline Tritonia festiva Stearns, 1873 & Den & No & $0.01 \pm 0.02$ & $0.00 \pm 0.00$ & - & 0.36 & $\mathrm{~N}$ \\
\hline Hermissenda crassicornis (Eschscholtz, 1831) & Aeo & Yes & $7.24 \pm 4.60$ & $1.25 \pm 1.56$ & - & 0.002 & $\mathrm{~W}$ \\
\hline Doto amyra Marcus, 1961 & Den & Yes & $3.11 \pm 6.12$ & $0.42 \pm 0.55$ & - & 0.12 & $\mathrm{~N}$ \\
\hline Flabellina trilineata O’Donoghue, 1921 & Aeo & Yes & $1.84 \pm 1.16$ & $1.29 \pm 0.91$ & - & 0.19 & $\mathrm{~N}$ \\
\hline Cuthona flavovulta (MacFarland, 1966) & Aeo & Yes & $0.77 \pm 0.91$ & $0.77 \pm 1.44$ & 0 & 0.42 & $\mathrm{~S}$ \\
\hline Cuthona divae (Marcus, 1961) & Aeo & Yes & $0.39 \pm 0.44$ & $0.15 \pm 0.23$ & - & 0.13 & $\mathrm{~N}$ \\
\hline Doto kya Marcus, 1961 & Den & Yes & $0.30 \pm 0.62$ & $0.00 \pm 0.00$ & - & 0.10 & $\mathrm{~N}$ \\
\hline Cuthona albocrusta (MacFarland, 1966) & Aeo & Yes & $0.27 \pm 0.34$ & $0.00 \pm 0.00$ & - & 0.04 & $\mathrm{~W}$ \\
\hline Aeolidiella oliviae MacFarland, 1966 & Aeo & Yes & $0.11 \pm 0.20$ & $0.00 \pm 0.00$ & - & 0.10 & $\mathrm{~S}$ \\
\hline Cuthona abronia (MacFarland, 1966) & Aeo & Yes & $0.10 \pm 0.21$ & $0.43 \pm 0.66$ & + & 0.82 & $\mathrm{~N}$ \\
\hline Aeolidia papillosa (Linnaeus, 1761) & Aeo & Yes & $0.08 \pm 0.19$ & $0.11 \pm 0.24$ & + & 0.57 & $\mathrm{~N}$ \\
\hline Doto columbiana O’Donoghue, 1921 & Den & Yes & $0.04 \pm 0.09$ & $0.25 \pm 0.56$ & + & 0.76 & $\mathrm{~N}$ \\
\hline Dendronotus venustus MacFarland, 1966 & Den & Yes & $0.03 \pm 0.08$ & $0.00 \pm 0.00$ & - & 0.18 & $\mathrm{~N}$ \\
\hline Eubranchus rustyus (Marcus, 1961) & Aeo & Yes & $0.02 \pm 0.05$ & $0.00 \pm 0.00$ & - & 0.18 & $\mathrm{~W}$ \\
\hline Cuthona fulgens (MacFarland, 1966) & Aeo & Yes & $0.00 \pm 0.00$ & $0.10 \pm 0.22$ & + & 0.81 & $\mathrm{~N}$ \\
\hline Phidiana hiltoni (O’Donoghue, 1927) & Aeo & Yes & $0.00 \pm 0.00$ & $10.44 \pm 5.71$ & + & $<0.001$ & S \\
\hline
\end{tabular}

Species are grouped by vulnerability to $P$. hiltoni as outlined in "Materials and methods" and ranked by mean abundance during $1969-1975$. $\Delta=$ change in abundance. Probabilities $(P)$ are for $t$-tests (assuming unequal variances) of log-transformed abundances for the two time periods, two-tailed for $P$. hiltoni and species considered not vulnerable to $P$. hiltoni, and one-tailed for species deemed vulnerable. Nomenclature follows Behrens and Hermosillo (2005) and Stout et al. (2010). Taxon codes: Dor Doridina, Arm Arminina, Aeo Aeolidina, Den Dendronotina. Geographic range categories: $N$ northern, $S$ southern, $W$ widespread (see "Materials and methods") 


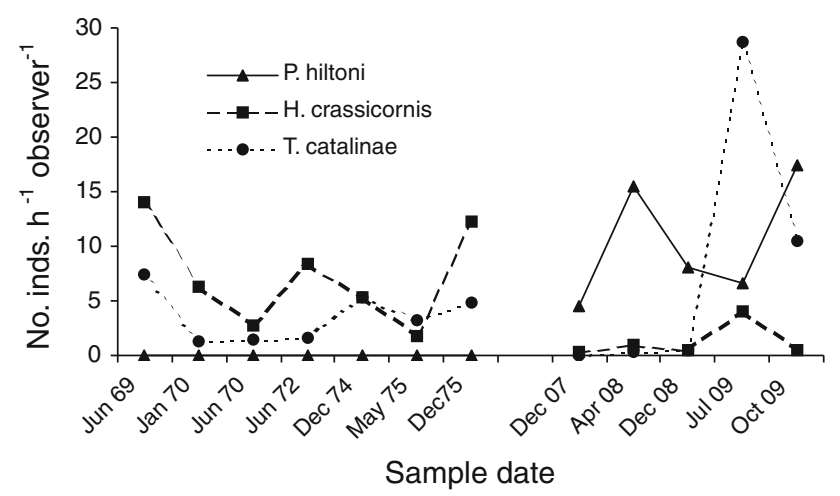

Fig. 4 Changes in abundance of Phidiana hiltoni, Triopha catalinae, and Hermissenda crassicornis at Duxbury Reef between 1969-1975 and 2007-2009
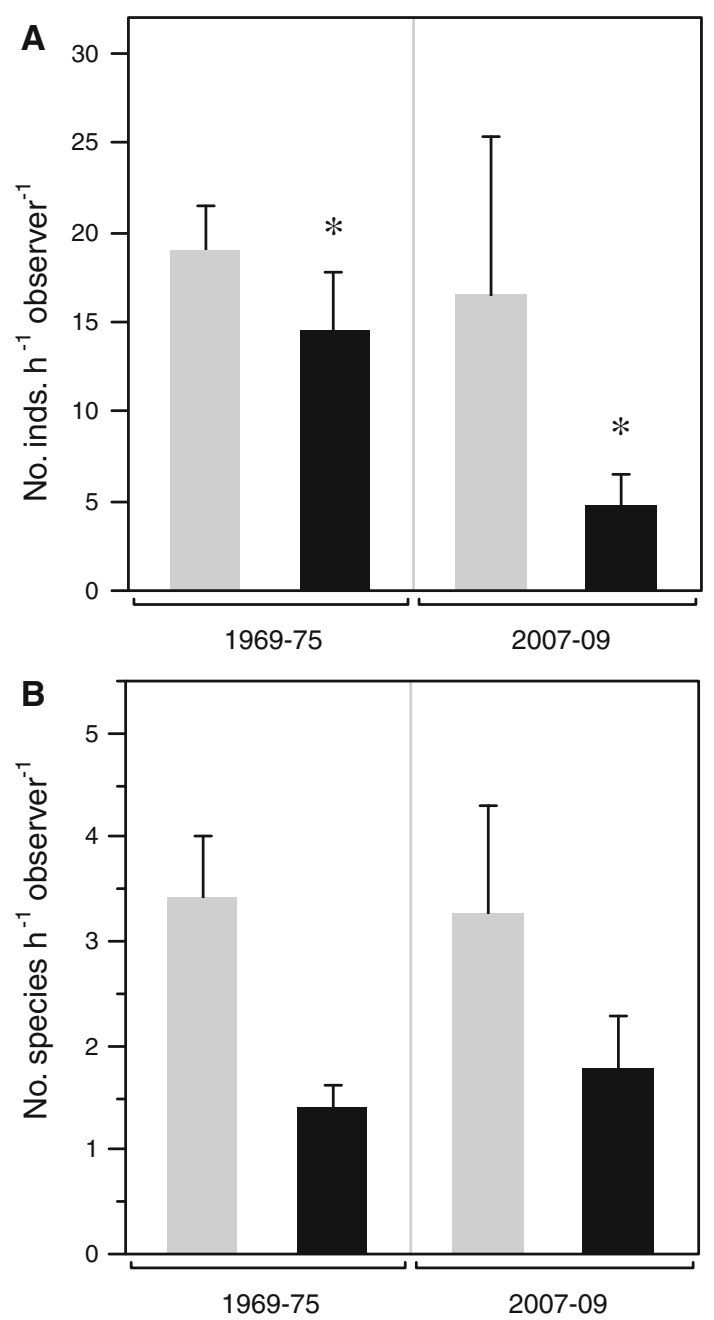

Fig. 5 Mean number ( + SE) of a individuals and b species of nudibranchs found at Duxbury Reef during 1969-1975 ( $n=7$ counts) and 2007-2009 ( $n=5$ counts), grouped by species vulnerability to predation by $P$. hiltoni as outlined in "Materials and methods". Key: gray, not vulnerable; black, vulnerable. Asterisks (*) indicate pairs of values for the different time periods significantly different at $P<0.05$ by a one-tailed $t$-test assuming unequal variances
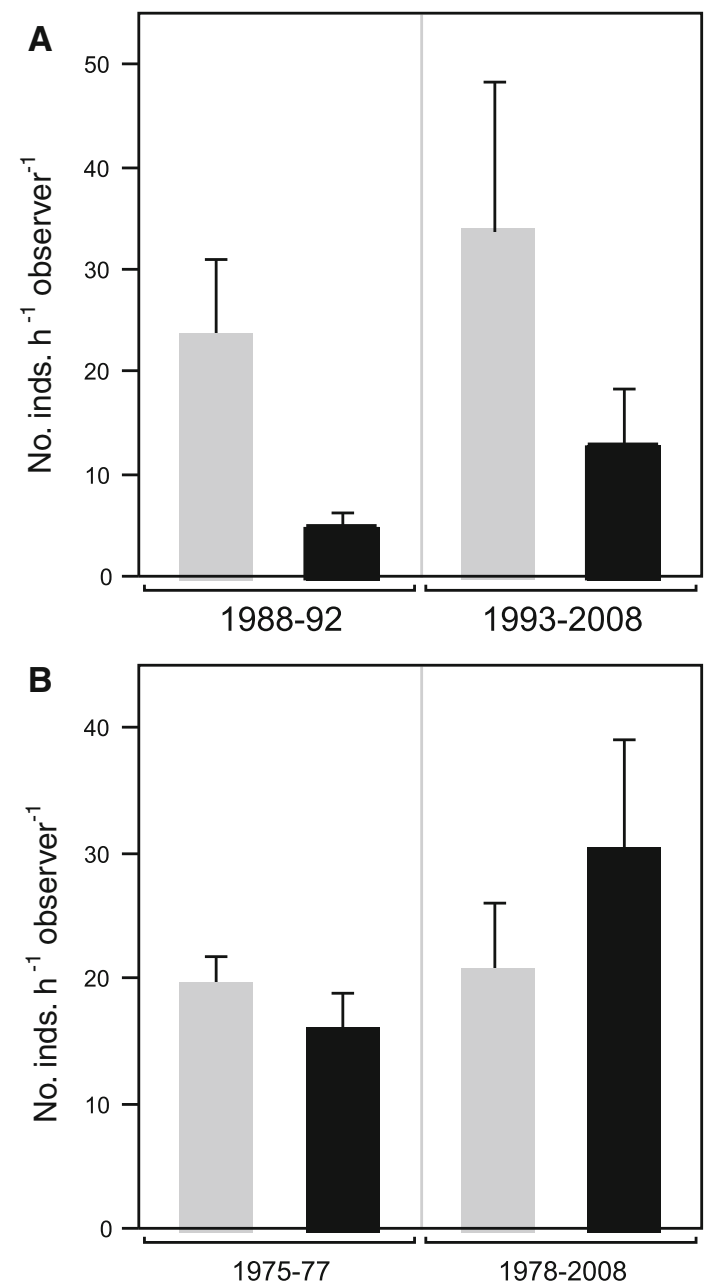

Fig. 6 Mean number (+SE) of nudibranchs found at a Pillar Point and $\mathbf{b}$ Scott Creek, before and after arrival of $P$. hiltoni, grouped by species vulnerability to predation by $P$. hiltoni. Gray not vulnerable; black vulnerable

Table 4 Proportion of nudibranch species tending to increase or decrease in abundance at Duxbury Reef following arrival of $P$. hiltoni, grouped by vulnerability to $P$. hiltoni and geographic range as in Table 3

\begin{tabular}{|c|c|c|c|c|}
\hline \multirow[t]{2}{*}{ Change in abundance } & \multicolumn{2}{|c|}{ Vulnerable to $P$. hiltoni } & \multicolumn{2}{|c|}{ Geographic range } \\
\hline & Yes & No & $\mathrm{N}$ & $\mathrm{S}$ and $\mathrm{W}$ \\
\hline Increase & 0.31 & 0.32 & 0.45 & 0.13 \\
\hline Decrease & 0.69 & 0.68 & 0.55 & 0.87 \\
\hline \multicolumn{5}{|l|}{ Vulnerable to $P$. hiltoni } \\
\hline Yes & - & - & 0.64 & 0.36 \\
\hline No & - & - & 0.52 & 0.48 \\
\hline
\end{tabular}

Proportions based on Table 3, columns 3, 6, and 8. Abundance changes were similar for southern and widespread species, so these two groups were combined 


\section{Discussion}

Range expansion and abundance of Phidiana hiltoni

Phidiana hiltoni was clearly not present north of the Monterey Peninsula in the 1950s, 1960s, and early 1970s (Appendix). Its subsequent northward spread coincided with the shift in 1976-1977 from cool to warm phase of the Pacific Decadal Oscillation (Mantua and Hare 2002) and may have been driven by larval advection via increased poleward transport of coastal waters. Some of the hydroids consumed by $P$. hiltoni are epiphytic, and $P$. hiltoni has been observed on kelp (MacFarland 1966). Therefore, rafting of egg masses or post-metamorphic stages on drifting macrophytes may also have contributed to the northward spread of $P$. hiltoni in the 1970s. The minimum average rate of spread of $P$. hiltoni from Monterey to Duxbury Reef was $6.7 \mathrm{~km} \mathrm{year}^{-1}$, within the range reported by Sorte et al. (2010) for other native marine gastropods from temperate regions.

Although the warm phase of the PDO appears to have ended in 2007 (Mantua 2010) and was followed by a strong La Niña and cooler sea surface temperatures in the California Current system in 2008 (McClatchie et al. 2008), $P$. hiltoni has persisted in its expanded range and remains one of the most abundant nudibranchs at Duxbury Reef.

Additional evidence suggests that $P$. hiltoni did not occur north of Monterey during the previous warm phase of the PDO, which lasted from 1925 to 1946 (Mantua 2010). Searches of the California Academy of Sciences Invertebrate Zoology (CASIZ) collections database (http:// research.calacademy.org/izg/collections/) revealed that collections of nudibranchs were made during this period from Santa Cruz County, on the north side of Monterey Bay, to Point Reyes (including some by F. M. MacFarland, who recognized $P$. hiltoni on the Monterey Peninsula as early as 1904 [e.g., CASIZ catalog number 68538], before it had been described). However, none of these collections included $P$. hiltoni (or its synonyms). The range shift of $P$. hiltoni may therefore constitute one of the first documented effects of global warming on the nudibranch fauna of the region.

At least two other shallow-water marine invertebrates are known to have expanded their ranges northward along the California coast at about the same time as P. hiltoni. The large whelk Kelletia kelletii spread from southern California to Monterey in the 1970s (reviewed by Zacherl et al. 2003), and the volcano barnacle Tetraclita rubescens spread from the San Francisco Bay area $300 \mathrm{~km}$ to Cape Mendocino, probably beginning in the late 1970s to early 1980s (Connolly and Roughgarden 1998; Dawson et al. 2010). The timing of all three range shifts points to the increase in poleward transport of coastal waters when the
PDO shifts from cool to warm phase as the driving mechanism.

Despite its abundance at Duxbury Reef since 1992, including during the strong 1997-1998 El Niño, P. hiltoni does not appear to have spread farther north (Appendix). Neither lack of adequate prey or reproductive failure is limiting its spread. We have observed sexually mature individuals and their egg masses at Duxbury Reef, and both Plumularia spp. and Hydractinia sp. occur throughout the Oregonian Biogeographic Province (Kozloff 1996; Carlton 2007; pers obs) and are preyed on by many of the same nudibranchs found at Duxbury Reef (Goddard 1984, 1998). Fitch and Lavenburg (1975) reported that a shallow-water fish, the Mosshead Warbonnet, Chirolophis nugator, preys upon adult $P$. hiltoni. However, this species ranges from the Channel Islands to Alaska and therefore does not seem likely to be determining the northern distributional limit of $P$. hiltoni.

Phidiana hiltoni is one of the only two nudibranchs from the outer coast in this region with lecithotrophic development (Goddard 2004), and its larvae, which typically crawl upon hatching (JG, pers obs), may not be planktonic long enough to traverse Point Reyes, which extends prominently from the middle of $36 \mathrm{~km}$ of sandy beaches. During the spring/summer upwelling season, surface currents north of Point Reyes are predominately southward and offshore, and an upwelling shadow forms in the lee of Point Reyes, capable of trapping larvae in its cyclonic eddy until upwelling relaxes and alongshore flows reverse (Wing et al. 1995, 1998; Vander Woude et al. 2006; Morgan et al. 2009). The reversal process takes a few days, potentially beyond the larval duration of $P$. hiltoni. Surf-zone flows across Duxbury Reef, combined with cyclonic circulation in Bolinas Bay (Wilde et al. 1969), may further trap locally any larval $P$. hiltoni that happen to enter the water column.

Larval retention in the above oceanographic features would also explain the persistence of high population densities of $P$. hiltoni at Duxbury Reef. Elsewhere in California, a high density of $P$. hiltoni has been observed at Soquel Point, located in the upwelling shadow of northern Monterey Bay (Fig. 3; Appendix) (Graham and Largier 1997), while south of the Monterey Peninsula, P. hiltoni has been consistently abundant intertidally in the past decade only at Cayucos $\left(35^{\circ}\right.$ $26^{\prime} 53^{\prime \prime} \mathrm{N}, 120^{\circ} 54^{\prime} 37^{\prime \prime} \mathrm{W}$ ) and in the Shell Beach area (35 $09^{\prime} 11^{\prime \prime} \mathrm{N}, 120^{\circ} 40^{\prime} 29^{\prime \prime}$ ) (JG, unpubl data). Both of these latter sites are located at the northern end of bights in the coastline, consistent with the formation of upwelling shadows and retention of short-lived larvae (Graham and Largier 1997; Sponaugle et al. 2002; Roughan et al. 2005).

\section{Diet of Phidiana hiltoni}

Phidiana hiltoni in the wild preyed primarily on hydroids, especially Plumularia spp. and campanulariids, which 
dominated the diet by both frequency of occurrence (Table 1), and volume (pers obs). Some of the other taxa observed in the feces, especially Foraminifera, diatoms, filamentous microalgae, and free-living crustaceans, constituted only a small total proportion of the diet and probably had been consumed incidentally as a result of their occurrence on or among the hydroid prey of $P$. hiltoni.

Seventy-three percent of the $15 P$. hiltoni examined from Duxbury Reef had few recognizable remains in their feces, compared to $43 \%$ of 47 individuals from the other three sites combined. This might reflect a diet composed more of soft-bodied prey, such as the hydroid Hydractinia sp. and perhaps nudibranchs, which in turn might reflect a reduced availability of thecate hydroids. No data are available on the abundance of hydroids at this site, before or after the arrival of $P$. hiltoni, and a properly controlled, manipulative field experiment testing the direct effect of $P$. hiltoni on them is not feasible. That the effects could be significant, however, is suggested by the rapidity with which individual $P$. hiltoni consumed entire hydrocauli of Plumularia laginifera in the laboratory, leaving behind only stumps and stolons (pers obs).

In the laboratory feeding trials, $P$. hiltoni readily consumed a wide variety of small dendronotid and aeolid nudibranchs, the known diets of which are summarized in Table 5. Some, especially juveniles and species small as adults, may be consumed incidentally by $P$. hiltoni in the wild as they feed on their common hydroid prey. Others, judging by the rapidity with which they were attacked in the laboratory (e.g., Cuthona albocrusta species of Doto), may actually be preferred prey of $P$. hiltoni-or at least readily consumed when encountered. Because these trials were conducted one to two days after the $P$. hiltoni were collected, we do not consider the results an artifact of starvation or simple juxtaposition of the individuals tested. Phidiana hiltoni foraging for hydroid prey are likely to encounter many of these species: we have often found them together in the same tidepools at Duxbury Reef, including many of the same pools on the outer portions of the reef where, prior to the arrival of $P$. hiltoni, we often found high densities of small aeolids and dendronotids.

For those nudibranchs attacked by $P$. hiltoni in the laboratory, the time course and outcome were dependent on the species and relative sizes of $P$. hiltoni and the test nudibranch. Larger slugs took longer to ingest, either whole or in part, and frequently became lodged in the mouth for a few minutes as $P$. hiltoni worked to ingest them. All of the species of Doto used in the feeding trials are small as adults $(<10 \mathrm{~mm})$, but even some of these individuals became stuck and were only partially consumed, suggesting they pose physical impediments to ingestion by $P$. hiltoni. This was also the case for Eubranchus rustyus, an aeolid that can grow a little longer than the species of Doto, but that became stuck and were only partially consumed at 7 and $10 \mathrm{~mm}$ in length. For the size range of $P$. hiltoni we used, test slugs longer than about $15 \mathrm{~mm}$ were effectively immune to attack and therefore appear to have a refuge in size from predation by $P$. hiltoni.

Nudibranchs specializing on Plumularia spp. (Doto kya, Eubranchus rupium, and E. rustyus) sometimes or always repelled $P$. hiltoni, especially compared to congeners (e.g., Doto amyra and D. columbiana) that specialize on hydroids which $P$. hiltoni either does not consume or consumes less frequently (Tables 2, 5). A history of interactions between $P$. hiltoni and other species of nudibranchs sharing the same prey may therefore have led to the evolution of defensive adaptations against $P$. hiltoni.

The escape behaviors elicited in Dendronotus venustus and Hermissenda crassicornis by contact with P. hiltoni are certainly defensive and appeared to be mediated by contact chemoreception. On the open coast, all three species are often found crawling among short hydroids, including Plumularia spp. and campanulariids. The swimming escape response by $D$. venustus is similar to those of other nudibranchs after being contacted by predatory sea stars (Mauzey et al. 1968; Birkeland 1974; TA Wayne, pers comm; pers obs) and is likely more effective in the wild than under our artificial test conditions.

Phidiana hiltoni collected from Ellwood, Jalama, and Hazard Canyon were mostly repelled by Hermissenda crassicornis (Table 2), and most of the attacks observed on this species were by individuals collected from Duxbury Reef. Hermissenda crassicornis has a broad diet (Table 5), and variation in individual palatability to $P$. hiltoni might reflect dietary preferences and feeding history of $H$. crassicornis, or the hunger level of $P$. hiltoni, especially if the abundance of hydroid prey has been reduced.

Doto columbiana was always consumed by $P$. hiltoni in the laboratory (Table 2), but in the wild may not often be encountered by $P$. hiltoni, owing to its prey-and microhabitat; it specializes on Aglaophenia sp., a large bushy hydroid not consumed by $P$. hiltoni. Similar habitat refuges from predation have been documented for amphipod crustaceans (Hay et al. 1990).

\section{Ecological impact of Phidiana hiltoni at Duxbury Reef}

Taken together, nudibranchs vulnerable to $P$. hiltoni were less abundant at Duxbury Reef in 2007-2009 than in the 1960s and 1970s, before P. hiltoni arrived. Predation by $P$. hiltoni on these species, either directly by foraging individuals or indirectly by individuals consuming hydroids hosting small individuals of the vulnerable species, has likely factored in the overall decline in abundance. However, P. hiltoni may also be competing with some of 
Table 5 Summary of prey of nudibranchs from Duxbury Reef considered vulnerable to predation by Phidiana hiltoni

\begin{tabular}{|c|c|}
\hline Nudibranch & Prey \\
\hline \multicolumn{2}{|l|}{ Dendronotina } \\
\hline $\begin{array}{l}\text { Dendronotus } \\
\text { venustus }\end{array}$ & Campanulariidae, including Obelia spp. \\
\hline Doto amyra & Coryne sp., Garveia sp., Sertulariidae \\
\hline Doto columbiana & Aglaophenia spp. \\
\hline Doto kya & Plumularia sp. \\
\hline \multicolumn{2}{|l|}{ Aeolidina } \\
\hline Aeolidia papillosa & Actinaria \\
\hline Aeolidiella oliviae & Actinaria \\
\hline Cuthona abronia & Among small thecate hydroids \\
\hline $\begin{array}{l}\text { Cuthona } \\
\text { albocrusta }\end{array}$ & Among unbranched Campanulariidae \\
\hline Cuthona divae & Hydractinia sp. \\
\hline $\begin{array}{l}\text { Cuthona } \\
\text { flavovulta }\end{array}$ & Unidentified hydroids \\
\hline Cuthona fulgens & Sarsia sp. \\
\hline $\begin{array}{l}\text { Eubranchus } \\
\text { rustyus }\end{array}$ & Plumularia sp. \\
\hline $\begin{array}{l}\text { Flabellina } \\
\text { trilineata }\end{array}$ & $\begin{array}{l}\text { Pinauay marina, Eudendrium } \\
\text { californicum }\end{array}$ \\
\hline $\begin{array}{l}\text { Hermissenda } \\
\text { crassicornis }\end{array}$ & $\begin{array}{l}\text { Obelia sp., Plumularia sp., Pinauay marina } \\
\text { Actinaria, colonial ascidians }\end{array}$ \\
\hline
\end{tabular}

Based on records in McDonald and Nybakken (1978, 1997), Goddard (1984, 1996, 1998, 2006, unpubl. data), McDonald (2007), and Megina et al. (2007). Does not include prey records from outside the northeastern Pacific Ocean

these species by consuming large quantities of shared hydroid prey. Since arriving at Duxbury Reef, P. hiltoni has consistently been one of the most abundant nudibranchs (Table 3), and with its predatory abilities and large size - and concomitant energy requirements-likely has significant grazing impacts on Plumularia spp. and other hydroids in the wave-protected pools where it most frequently occurs. In more wave-exposed microhabitats on the seaward edge of the reef, $P$. hiltoni is less abundant, and hydroids, including the species of Hydractinia that $P$. hiltoni consumed in the laboratory, appear to be more abundant.

The lack of decline in the abundance of vulnerable nudibranchs at Pillar Point and Scott Creek, where P. hiltoni was much less abundant than at Duxbury Reef, further points to $P$. hiltoni as the probable cause of the decline at Duxbury Reef. Although significant declines were observed for only two species we categorized as vulnerable (Hermissenda crassicornis and Cuthona albocrusta), sample sizes were low, and variance in the counts high, reducing the likelihood of detecting significant changes in the seven other vulnerable species that tended to decline, the $P$-values for which were fairly low (Table 3 ).
Four species we categorized as vulnerable tended to increase in abundance (Table 3). Two of these (Cuthona abronia and $C$. fulgens) we were unable to obtain for use in feeding trials with $P$. hiltoni, so like $C$. lagunae may turn out to actually repel it. Of the other two species, Doto columbiana, though vulnerable in the laboratory feeding trials, may have a habitat refuge from predation by the aeolid (see above). Aeolidia papillosa, in addition to quickly growing to a size too large for $P$. hiltoni to handle (pers obs), may also have a habitat refuge when feeding on the clonal sea anemone Anthopleura elegantissima, its primary prey in the region.

Assuming P. hiltoni significantly reduced the abundance of its hydroid prey at Duxbury Reef, then it would have had to switch to other types of prey. Neither of the solitary corals consumed by P. hiltoni (see "Introduction") occurs in our study area at Duxbury Reef (pers obs). Other than possibly some sea anemones, that leaves mainly other nudibranchs. We might then expect $P$. hiltoni to consume vulnerable species as it encounters them, with the encounter rate reflecting the abundance of each species, and its habitat overlap with $P$. hiltoni. Under this scenario, it is not surprising then, that Hermissenda crassicornis not only appears to have been impacted the most (Table 3), but that its decline would account for most of the overall decline in abundance of the vulnerable species (Fig. 5a). Hermissenda crassicornis not only had been the most common species at Duxbury Reef, but was also consumed in the laboratory in most of the trials using $P$. hiltoni specifically from this site.

The lack of change in the number of species observed pre- and post-arrival of $P$. hiltoni for both groups of nudibranchs (Fig. 5b) indicates that vulnerable species have continued to recruit to Duxbury Reef and that some individuals find refuges from the negative effects of $P$. hiltoni. The habitat here is topographically complex and undoubtedly affords abundant spatial refuges, especially for smaller species. Once the larger species have reached their adult size, they are effectively immune to predation by $P$. hiltoni. Others, like Dendronotus venustus, have escape behaviors triggered by contact with $P$. hiltoni. A few of the more common species in California, like Hermissenda crassicornis and Flabellina trilineata, even if they were consistently consumed upon contact by $P$. hiltoni (not the case overall in this study), occasionally recruit in such high numbers that they likely swamp any ability of $P$. hiltoni to control them. This appeared to be the case in January and May 2010, when we observed high numbers of both species following the peak of the 2009 El Niño.

Any negative impact of $P$. hiltoni on nudibranchs at Duxbury Reef results from its large body size and high density. The latter, as discussed earlier, appears to stem from a combination of life history traits (large egg size, 
lecithotrophic development, and lack of a long-term larval stage) and coastal topography and oceanography. Given the apparently positive correlation on the California coast between the density of $P$. hiltoni and the presence of upwelling shadows, we expect that its negative impacts on the abundance of nudibranchs are largely confined to these distinctive sites (e.g., Soquel Point and Cayucos) and therefore are relatively localized within its greater geographic range. We expect the general pattern to hold should $P$. hiltoni spread further north.

Acknowledgments We thank Brenna Green, Rebecca Johnson, Meg Burke and Heather Gosliner for assisting with the sampling at Duxbury Reef, and Gwen Heistand, the Audubon Canyon Ranch, and Cal Goddard for material and logistical support. We also thank Brenna Green, Caroline Schooley, Douglas Mason, Gary McDonald, Jackie Sones, John Albers-Mead, Mary Ellen Hill, Sarah Lenz, and William Pence for sharing their observations on the distribution of Phidiana hiltoni. Douglas Mason graciously allowed us to use his image of $P$. hiltoni. The comments of anonymous reviewers improved the manuscript, and we are grateful for their efforts. This research was funded in part by grant R/OPCENV-08 from the California Ocean Protection Council and California Sea Grant to JG, TG, and JSP.

Open Access This article is distributed under the terms of the Creative Commons Attribution Noncommercial License which permits any noncommercial use, distribution, and reproduction in any medium, provided the original author(s) and source are credited.

\section{References}

Albers-Mead J (2006) Pugnacious aeolid. http://www.flickr. com/photos/jalbersmead/375833458/. Accessed 29 April 2010

Alder J, Hancock A (1846) A monograph of the British nudibranchiate Mollusca: with figures of all the species. Pt. 2. Ray Society, London

Behrens DW (2004) Pacific coast nudibranchs, supplement II, new species to the Pacific coast and new information on the oldies. Proc Calif Acad Sci 55:11-54

Behrens DW, Hermosillo A (2005) Eastern Pacific nudibranchs. Sea Challengers, Monterey

Bertsch H, Gosliner T, Wharton R, Williams G (1972) Natural history and occurrence of opisthobranch gastropods from the open coast of San Mateo County, California. Veliger 14:302-314

Birkeland C (1974) Interactions between a sea pen and seven of its predators. Ecol Monogr 44:211-232

California Department of Fish and Game (2007) California marine life protection act initiative. Draft North Central Coast Regional Profile, Appendix V http://www.dfg.ca.gov/mlpa/pdfs/nccrp/ appendix5.pdf. Accessed 19 April 2010

Carlton JT (ed) (2007) The Light and Smith manual: intertidal invertebrates from central California to Oregon. University of California Press, Berkeley

Clark T (2007) Phidiana hiltoni. http://week.divebums.com/2007/ May21-2007/index.html. Accessed 19 March 2010

Connolly SR, Roughgarden J (1998) A range extension for the volcano barnacle Tetraclita rubescens. Calif Fish Game $84: 182-183$
Costello DP (1938) Notes on the breeding habits of nudibranchs of Monterey Bay and vicinity. J Morphol 63:319-344

Dawson MN, Grosberg RK, Stuart YE, Sanford E (2010) Population genetic analysis of a recent range expansion: mechanisms regulating the poleward range limit in the volcano barnacle Tetraclita rubescens. Mol Ecol 19:1585-1605

Fitch JE, Lavenburg RJ (1975) Tidepool and nearshore fishes of California. University of California Press, Berkeley

Garcia JC, Garcia FJ (1984) Estudio anatomico y algunas resenas ecologicas de Godiva banyulensis (Portmann y Sandmeir) (Gastropoda: Nudibranchia). Cah Biol Mar 25:49-65

Goddard JHR (1984) The opisthobranchs of Cape Arago, Oregon, with notes on their biology and a summary of benthic opisthobranchs known from Oregon. Veliger 27:143-163

Goddard JHR (1996) Lecithotrophic development in Doto amyra (Nudibranchia: Dendronotacea), with a review of developmental mode in the genus. Veliger 39:43-54

Goddard JHR (1998) A summary of the prey of nudibranchs from Cape Arago, Oregon. Opisthobranch Newslett 24:11-14

Goddard JHR (2004) Developmental mode in opisthobranchs molluscs from the northeast Pacific Ocean: feeding in a sea of plenty. Can J Zool 82:1954-1968

Goddard JHR (2006) Doto columbiana O'Donoghue, 1921. Sea Slug Forum. Australian Museum, Sydney. http://www.seaslugforum. net/factsheet/dotocolu. Accessed 3 June 2010

Gosliner TM, Williams GC (1970) The opisthobranchs of Marin County, California. Veliger 13:175-180

Gosliner TM, Williams GC (1973) Additions to the opisthobranch mollusk fauna of Marin County, California, with notes on their natural history. Veliger 15:352-354

Graham WM, Largier JL (1997) Upwelling shadows as nearshore retention sites: the example of northern Monterey Bay. Cont Shelf Res 17:509-532

Green B (2009) A Phidiana hiltoni takes a bite from a Plumularia hydroid. http://www.flickr.com/photos/lemurdillo/4076418935/. Accessed 19 April 2010

Hay ME, Duffy JE, Fenical W (1990) Host-plant specialization decreases predation on a marine amphipod-an herbivore in plants clothing. Ecol 71:733-743

Kintisch E (2008) Impacts research seen as next climate frontier. Science 322:182-183

Kozloff EN (1996) Marine invertebrates of the Pacific Northwest. With additions and corrections. University of Washington Press, Seattle

Lance JR (1962) Two new opisthobranch mollusks from southern California. Veliger 4:155-159

MacFarland FM (1966) Studies of opisthobranchiate mollusks of the Pacific coast of North America. Mem Calif Acad Sci 6:1-546

Mantua NJ (2010) The Pacific decadal oscillation (PDO). http:// jisao.washington.edu/pdo/PDO.latest. Accessed 2 September 2010

Mantua NJ, Hare SR (2002) The Pacific decadal oscillation. J Oceanog 58:35-44

Marques AC, Migotto AE, Calder DR, Mills CE (2007) Key to the polypoid stages of Hydrozoa. In: Carlton JT (ed) The Light and Smith manual: intertidal invertebrates from central California to Oregon. University of California Press, Berkeley, pp 124-137

Mauzey KP, Birkeland C, Dayton PK (1968) Feeding behavior of asteroids and escape responses of their prey in the Puget Sound region. Ecol 49:603-619

McClatchie S, Goericke R, Koslow JA et al. (2008) The state of the California current, 2007-2008: La Niña conditions and their effects on the ecosystem 2008. Calif Coop Ocean Fish Invest Rep 49:39-76

McDonald GR (1983) A review of the nudibranchs of the California coast. Malacologia 24:114-276 
McDonald GR (2007) Sacoglossa and Nudibranchia. In: Carlton JT (ed) The Light and Smith manual: intertidal invertebrates from central California to Oregon. University of California Press, Berkeley, pp 788-807

McDonald GR, Nybakken JW (1978) Additional notes on food of some California nudibranchs with a summary of known foodhabits of California species. Veliger 21:110-119

McDonald GR, Nybakken JW (1997) A list of the Worldwide food habits of nudibranchs. http://www.theveliger.org/nudibranch food.html. Accessed 3 June 2010

McGowan JA, Bograd SJ, Lynn RJ, Miller AJ (2003) The biological response to the 1977 regime shift in the California Current. Deep-Sea Res II 50:2567-2582

Megina C, Gosliner T, Cervera JL (2007) The use of trophic resources by a generalist aeolid nudibranch Hermissenda crassicornis (Mollusca: Gastropoda). Cah Biol Mar 48:1-7

Montoya JM, Raffaelli D (2010) Climate change, biotic interactions and ecosystem services introduction. Phil Trans Roy Soc London B 365:2013-2018

Morgan SG, Fisher JL, Miller SH, McAfee ST, Largier JL (2009) Nearshore larval retention in a region of strong upwelling and recruitment limitation. Ecol 90:3489-3502

Nybakken JW (1978) Abundance, diversity and temporal variability in a California intertidal nudibranch assemblage. Mar Biol 45:129-146

O'Donoghue CH (1927) Notes on a collection of nudibranchs from Laguna Beach, California. J. Entomol Zool (Pomona College, Claremont, California) 19:77-119

Paine RT (1963) Food recognition and predation on opisthobranchs by Navanax inermis. Veliger 6:1-9

Parmesan C, Yohe G (2003) A globally coherent fingerprint of climate change impacts across natural systems. Nature 421:37-42

Penney BK (2006) Morphology and biological roles of spicule networks in Cadlina luteomarginata (Nudibranchia, Doridina). Invert Biol 125:222-232

Perry AL, Low PJ, Ellis JR, Reynolds JD (2005) Climate change and distribution shifts in marine fishes. Science 308:1912-1915

Roller RA (1970) A list of recommended nomenclatural changes for MacFarland's "Studies of opisthobranchiate mollusks of the Pacific coast of North America". Veliger 12:371-374

Roughan M, Mace AJ, Largier JL, Morgan SG, Fisher JL, Carter ML (2005) Subsurface recirculation and larval retention in the lee of a small headland: A variation on the upwelling shadow theme. J Geophys Res 110:C10027. doi:10.1029/2005JC002898

Schultz ST, Goddard JHR, Gosliner TM, Mason DE, Pence WE, McDonald GR, Pearse VB, Pearse JS (2011) Climate-index response profiling indicates larval transport is driving population fluctuations in nudibranch gastropods from the northeast Pacific Ocean. Limnol Oceanog (in press)

Sorte CJB, Williams SL, Carlton JT (2010) Marine range shifts and species introductions: comparative spread rates and community impacts. Global Ecol Biogeogr 19:303-316

Sponaugle S, Cowen RK, Shanks A, Morgan SG, Leis JM, Pineda J, Boehlert GW, Kingsford MJ, Lindeman KC, Grimes C, Munro
JL (2002) Predicting self-recruitment in marine populations: biophysical correlates and mechanisms. Bull Mar Sci 70(suppl):341-375

Steinberg JE (1963) Notes on the opisthobranchs of the west coast of North America-IV. A distributional list of opisthobranchs from Point Conception to Vancouver Island. Veliger 6:68-73

Stout CA, Pola M, Valdés Á (2010) Phylogenetic analysis of Dendronotus nudibranchs with emphasis on northeastern Pacific species J Moll Stud. 76:367-375

Thompson TE (1964) Grazing and the life cycles of British nudibranchs. In: Grazing in terrestrial and marine environments. Brit Ecol Soc Symp 4:275-297

Thompson TE (1976) Biology of opisthobranch molluscs, vol I. Ray Society, London

Thompson TE, Brown GH (1984) Biology of opisthobranch molluscs, vol II. Ray Society, London

Van der Putten WH, Macel M, Visser ME (2010) Predicting species distribution and abundance responses to climate change: why it is essential to include biotic interactions across trophic levels. Phil Trans Roy Soc London B 365:2025-2034

Vander Woude AJ, Largier JL, Kudela RM (2006) Nearshore retention of upwelled waters north and south of Point Reyes (northern California) - patterns of surface temperature and chlorophyll observed in CoOP WEST. Deep-Sea Res 53:29852998

Walther GR (2010) Community and ecosystem responses to recent climate change. Phil Trans Roy Soc London B 365:2019-2024

Wight B (2000) Phidiana hiltoni feeding. Sea Slug Forum. Australian Museum, Sydney. Available from http://www.seaslugforum. net/find/2715. Accessed 19 March 2010

Wilde P, Isselhardt C, Osuch L, Yancey T (1969) Recent sediments of Bolinas Bay, California. Part C. Interpretation and summary of results. Hydraulic Engineering Laboratory, College of Engineering, University of California, Berkeley, California. Available from http://www.marscigrp.org/hel223.pdf. Accessed 12 December 2010

Wing SR, Botsford L, Largier JL, Morgan LE (1995) Spatial variability in settlement of benthic invertebrates in a northern California upwelling system. Mar Ecol Prog Ser 128:199-211

Wing SR, Botsford LW, Ralston SV, Largier JL (1998) Meroplanktonic distribution and circulation in a coastal retention zone of the northern California upwelling system. Limnol Oceanogr 43:1710-1721

Wolter K, Timlin MS (1993) Monitoring ENSO in COADS with a seasonally adjusted principal component index. In: Proceedings of 17th climate diagnostics workshop, Norman, OK, NOAA/ NMC/CAC, NSSL, Oklahoma Clim. Survey, CIMMS and the School of Meteor., Univ. of Oklahoma, pp 52-57. Available from http://www.esrl.noaa.gov/psd/people/klaus.wolter/MEI/ mei.html\#ref_wt1. Accessed 17 Dec 2010

Zacherl D, Gaines SD, Lonhart SI (2003) The limits to biogeographical distributions: insights from the northward range extension of the marine snail, Kelletia kelletii (Forbes, 1852). J Biogeog 30:913-924 